\title{
CELL-BASED THERAPY FOR THE TREATMENT OF FOCAL ARTICULAR CARTILAGE LESIONS: A REVIEW OF SIX YEARS OF STUDIES IN A MALAYSIAN UNIVERSITY MEDICAL CENTRE
}

\author{
Samsudin EZ, Kamarul T \\ Clinical Investigation Centre, University Malaya Medical Centre, Kuala Lumpur
}

\author{
Correspondence: \\ Ely Zarina Samsudin, \\ Clinical Investigation Centre, University Malaya Medical Centre, \\ 59100 Kuala Lumpur. \\ Tel: +603-79492886; Fax: +603-79541904 \\ Email: elyzarina07@yahoo.com
}

\begin{abstract}
Autologous chondrocyte implantation $(\mathrm{ACl})$ is a significant technique that has gained widespread use for the treatment of focal articular cartilage damage. Since its inception in 2004, the Tissue Engineering Group (TEG) of the Faculty of Medicine, University Malaya has been dedicated to carrying out extensive research on this cell-based therapy. The objective of this report, comprising one clinical case report, six animal studies and one laboratory study, is to summarise and discuss TEG's key findings. On the whole, we observed that the $\mathrm{ACl}$ technique was effective in regenerating hyaline-like cartilage in treated defects. Autologous chondrocytes and mesenchymal stem cells (MSC) were found to produce comparable tissue repair irrespective of the state of MSC differentiation, and the use of alginate-based scaffolding and oral pharmacotherapy (Glucosamine and Chondroitin Sulphate) was shown to enhance $\mathrm{ACl}$-led tissue repair. $\mathrm{ACl}$ is suggested to be an efficient therapeutic option for the treatment of articular cartilage defects of the knee.
\end{abstract}

Keywords: articular cartilage, cell therapy, autologous chondrocyte implantation, animal studies, review

\section{Introduction}

The treatment of articular (hyaline) cartilage injuries is one of the most difficult challenges for orthopaedic surgeons. As aptly stated by William Hunter in 1743, 'an ulcerated cartilage is a troublesome problem and once destroyed, it never repairs'. This is because articular cartilage is avascular, with very limited healing capacity. Injury to articular cartilage begins an inexorable cascade of pathobiological and pathomechanical events that lead towards loss of tissue and formation of defect, in contrast with the process of inflammation and repair found in vascularized tissue. If left untreated, articular cartilage lesions invariably progress in size and lead to degenerative changes typical of osteoarthritis (1-2).

Articular cartilage lesions can result from sports injuries, trauma, osteoarthritis or osteochondritis. In Malaysia, symptomatic knee osteoarthritis is responsible for the largest burden of joint pain and is the single most important rheumatological cause of disability and handicap. A Community Oriented Program for Control of Rheumatic Diseases (COPCORD) survey conducted in 2007, involving a total of 2594 community members from Banting, revealed that $9.3 \%$ of adult Malaysians complain of knee pain, with clinical evidence of osteoarthritis in more than half those examined for knee pain (3). The incidence was noted to be higher in the aging population, with a sharp increase in pain rate to $23 \%$ in those over 55 years of age, and $39 \%$ in those over $65 \%$. For those who suffer from degenerative joint disease, the ability to regenerate cartilage would reduce the need for joint replacement, decrease pain, increase mobility and lead to a better quality of life.

As such, the restoration of articular cartilage defects is of paramount importance due to an urgent and expanding clinical need, especially with the expected $269 \%$ increase in the elderly (above 65 years) population in Malaysia between the years 2008 and 2040 (4). In recent years, the cell-based therapy termed autologous chondrocyte implantation $(\mathrm{ACl})$ has emerged as a promising technique to repair full-thickness chondral defects. The early work done by Hui et al of the National University of Singapore (NUS) in 1999 involving 52 Singaporean patients reported a symptomatic improvement in $90.2 \%$ of patients, with no adverse reaction to surgery (5). However, there are minimal data on the efficiency of the $\mathrm{ACl}$ technique in Asian populations available at present. Since its inception in 2004, the Tissue Engineering Group (TEG) of the Faculty 
of Medicine, University Malaya has been dedicated to carrying out extensive research on the $\mathrm{ACl}$ technique, with the aim of advancing knowledge and repair outcomes in the treatment of articular cartilage defects. In particular, we have directed our investigations towards focal articular cartilage lesion of the knee, defined as a circumscribed, full-thickness cartilage defect down to, but not through, the subchondral bone on a load-bearing surface of the femoral condyle or patellar facet.

The objective of this report is to present TEG's six years of experience in engineering cartilage cell therapy from the year 2007 to 2012. We have embarked on a collective appraisal of our centre-led trials (clinical, animal, laboratory studies) and scientific literature to discuss and compare our findings with previously published data. In particular, we aim to: 1) provide an overview of cartilage surgical repair techniques; 2 ) examine the clinical outcome and regenerative profile of conventional $\mathrm{ACl} ; 3$ ) discuss the chondrogenic potential of transplanted cells; 4 ) discuss the role of cell carriers and scaffolds; and 5) discuss the role of local and systemic pharmacological agents.

\section{An overview of cartilage surgical repair techniques}

A number of orthopaedic surgical procedures have been developed in an attempt to alter the otherwise dismal natural history of chondral defects. Arthroscopic debridement was the earliest technique utilised to treat articular cartilage defects of the knee. Although this procedure was shown to provide clinical improvements (6-9), the benefits were short-lived and the technique did not address the underlying pathology (10-12). Attempts were then made to improve the long-term results of cartilage repair by directing treatment towards exploiting the natural intrinsic repair response, observed upon penetration of the subchondral bone in full-thickness defects. Methods that accomplish this type of repair are termed marrow stimulation treatment (MST) techniques, and include subchondral drilling, abrasion arthroplasty and microfracture. In MST, subchondral bone is perforated to induce mesenchymal stem cell infiltration into a chondral defect, which leads to the formation of a clot that may differentiate into repair tissue. While MST procedures have demonstrated good to excellent results in $60-80 \%$ of patients (13-14), they typically promote the development of fibrocartilage that is biomechanically inferior to articular cartilage (10-12,15-16) and deteriorates over a short period of time postoperatively (16-18).

In 1965, Audrey Smith was able to culture chondrocytes in vitro after freezing, culminating in the advent of cryopreservation. This led to modern cartilage transplantation techniques, which include perichondral and osteochondral grafts. Perichondral grafts harvested from donor sites and implanted into chondral defects have been shown to lead to marked functional improvement $(19,20)$.
Osteochondral grafts, which harvest osteochondral plugs from low weight-bearing areas within the knee joint for implantation into chondral defects, have shown promising results with a success rate of up to $80 \%$ (21-25). Although both these techniques are able to retain the viability of hyaline tissue unlike previous surgical interventions (20, 26), perichondral grafts are susceptible to ossification and graft failure $(10,20)$ while osteochondral grafts are limited by donor site morbidity concerns $(10)$ and the lack of lateral integration of mosaic plugs and recipients, which may lead to degeneration of the graft over time $(17,27)$.

In recent years, the numerous experimental attempts to reestablish structurally and functionally competent repair tissue which is of an enduring nature has led to the advent of autologous cell extraction for implantation into chondral defects. A Swedish group led by Lars Peterson and Mats Brittberg was the first to describe the technique of autologous chondrocyte implantation ( $\mathrm{ACl}$ ) in 1984 (28), which was the first application of a cell-based approach in orthopaedic surgery. As previous studies had shown the ability of autologous cells to regenerate cartilage, Peterson et al refined a three-step procedure where chondrocytes isolated from cartilage biopsy were harvested arthroscopically from a non weight-bearing area, isolated enzymatically and expanded in a monolayer culture, and then implanted into the cartilage defect using a periosteal patch over the defect as a method of cell containment. Encouraged by their early success in rabbit models, the Swedish group refined the technique to culture autologous chondrocytes from a small sample of patients' own normal articular cartilage, and began a clinical trial to treat full-thickness defects in patients' knees.

In a variation of $\mathrm{ACl}$, Wakitani et al exploited the self-repair potential of mesenchymal stem cells (MSC) in treating chondral defects (29). MSC are pluripotent progenitor cells that can be ex vivo expanded and induced, either in vitro or in vivo, to terminally differentiate into chondrocytes. They have emerged as a potential cell source for cartilage cell therapy due to their multipotential capacity, easy isolation and culture, and high ex vivo expansive potential in governing the rapid and specific repair of skeletal tissues $(30,31)$. Aside from cells, recent advancements in cartilage cell therapy have focused on exploring the potential of chondro-conductive scaffolds and biofactors in further improving articular cartilage repair, giving rise to the terms 'second-generation' and 'third-generation' $\mathrm{ACl}$.

The usage of $\mathrm{ACl}$ in the repair of cartilage has generated much interest within the orthopaedic community, and there have been numerous studies reporting on $\mathrm{ACl}$. A systematic review published in 2011 by our centre suggested that there were at least 568 scientific papers reporting controlled and randomised clinical studies related to $\mathrm{ACl}$, involving 1,644 patients in total (32). In this paper, comparison with other treatments suggested that $\mathrm{ACl}$ is associated with superior structural regeneration of cartilage tissues and better clinical outcomes when compared with microfracture, similar or superior outcomes 
when compared with mosaicplasty, and comparable outcomes when compared with MSC transplantation and matrix-assisted autologous chondrocyte implantation $(\mathrm{MACl})$, both of which are techniques adapted from $\mathrm{ACl}$. Many authors comparing the $\mathrm{ACl}$ technique with another treatment modality reported more favourable results for $\mathrm{ACl}$ (33-38). However, there were also authors who reported comparable (39-41) or less favourable results (42) for $\mathrm{ACl}$. Early systematic reviews examining the evidence for $\mathrm{ACl}$ concluded that there was insufficient evidence from the existing literature to determine whether conventional $\mathrm{ACl}$ was superior in the treatment of focal articular cartilage defects (43-49). However, the $\mathrm{ACl}$ technique has evolved considerably over the past few years. As mentioned earlier, the induction of biomaterial-based scaffolding, alternative cell sources and biofactors are anticipated to improve the outcome of $\mathrm{ACl}$-led cartilage repair, which will be discussed in the following text.

\section{An overview of the studies performed in TEG}

The TEG studies investigating the $\mathrm{ACl}$ technique for the treatment of focal articular cartilage defects are illustrated in Table 1. There is a total of eight studies included in this paper, comprising a clinical case report, six animal studies and one laboratory study. There were no adverse effects observed in any of the studies.

\section{The clinical outcomes and regenerative profile of the conventional ACl technique}

Our first attempt to establish the clinical outcomes of conventional $\mathrm{ACl}$ (i.e. utilising autologous chondrocyte and periosteal patch) in our centre was a preliminary case report of two patients (50). In this study, we observed clinical improvements in both patients following $\mathrm{ACl}$-led repair of articular cartilage defects as evidenced by the International Knee Documentation Committee score, Oxford Knee Score and American Knee Society Score at nine months postoperatively (Table 1). Complete filling of treated chondral defects with repair tissue was also demonstrated via magnetic resonance imaging at six months. No complications were observed in both patients during the study period. Our early clinical findings suggested that the $\mathrm{ACl}$ technique could be applied in clinical practice for the treatment of chondral defects.

As the compositional changes in repair tissues are known to have major influences on their physiological function, we sought to determine the quality of cartilage regenerated following conventional $\mathrm{ACl}$ repair. In order to perform a quantitative and qualitative assessment of regenerated tissue, we opted to examine the glycosaminoglycan (GAG) content and Brittberg score. GAG plays a significant role in regulating the chondrocyte phenotype and is a determinant of the biochemical and mechanical quality of regenerated cartilage (51), whilst the Brittberg score has been found to be statistically reliable and repeatable for the macroscopic assessment of cartilage repair (52). In our later studies, we also used the O'Driscoll score, a validated measure for histological scoring (53), as an outcome measure.

Using nine rabbit models, identical full-thickness defects were created in the articular cartilage of both knees, and a month later the right knee was repaired via $\mathrm{ACl}$ while the left knee was left untreated (control group) (54). At three months post-surgery, enhanced macroscopic regeneration, significantly $(p=0.008)$ higher cellular expression of GAG and significantly $(p=0.007)$ higher mean Brittberg repair score were observed in the $\mathrm{ACl}$-treated knees compared to the control group (Table 1). The study suggested that articular lesions treated by $\mathrm{ACl}$ repaired better than those which were not treated.

The work done by other centres has also reported a significant amount of cartilage reconstitution in $\mathrm{ACl}$-treated defects in both preclinical $(28,55-56)$ and clinical studies (57-61). The clinical trial conducted by the pioneering Swedish group led by Peterson and Brittberg, spanning a mean follow-up of 39 months, showed good or excellent clinical outcomes in $87 \%$ of cases ( $n=23$ ) and 'hyaline-like' results in 11 out of 15 treated lesions (57). A more recent publication from this group has shown durable results up to 11 years, with $96 \%$ clinical durability (60), and a correlation of good and excellent clinical results with the generation of hyaline-like repair tissue (62). However, not all reports have been favourable. Horas et al (42) compared ACl with osteochondral cylinder transplantation, and reported slower recovery and fibrocartiliginous defect filling for $\mathrm{ACl}$-treated patients. Moreover, despite its promising tissue repair potential, several complications arising from the use of conventional $\mathrm{ACl}$ have been reported. These include periosteal hypertrophy, disturbed fusion of regenerative cartilage and healthy surrounding cartilage, and dedifferentiation of cellular phenotypes cultured in a monolayer culture (63-67). Although ACl has been shown to produce satisfactory short and medium-term results, further technique improvements are needed to address the typical complications associated with $\mathrm{ACl}$.

\section{The chondrogenic potential of transplanted cells}

Chondrocytes, responsible for the secretion of extracellular matrix, were initially the logical and preferred cell source for cell-based cartilage engineering. Although found to produce good outcomes, their use in various models was shown to be limited by issues of donor site morbidity and cellular dedifferentiation when cultured in vitro (65-67). In recent years, MSC has emerged as a promising alternative cell source for cartilage repair. MSC, responsible for bone and cartilage formation in the embryo, and repair and turnover in the adult, are multipotent stem cells with the potential of differentiating into adipocytes, chondrocytes or osteocytes. The multipotency of MSC enables them to be stable phenotypes in vitro as well as progenitors for 


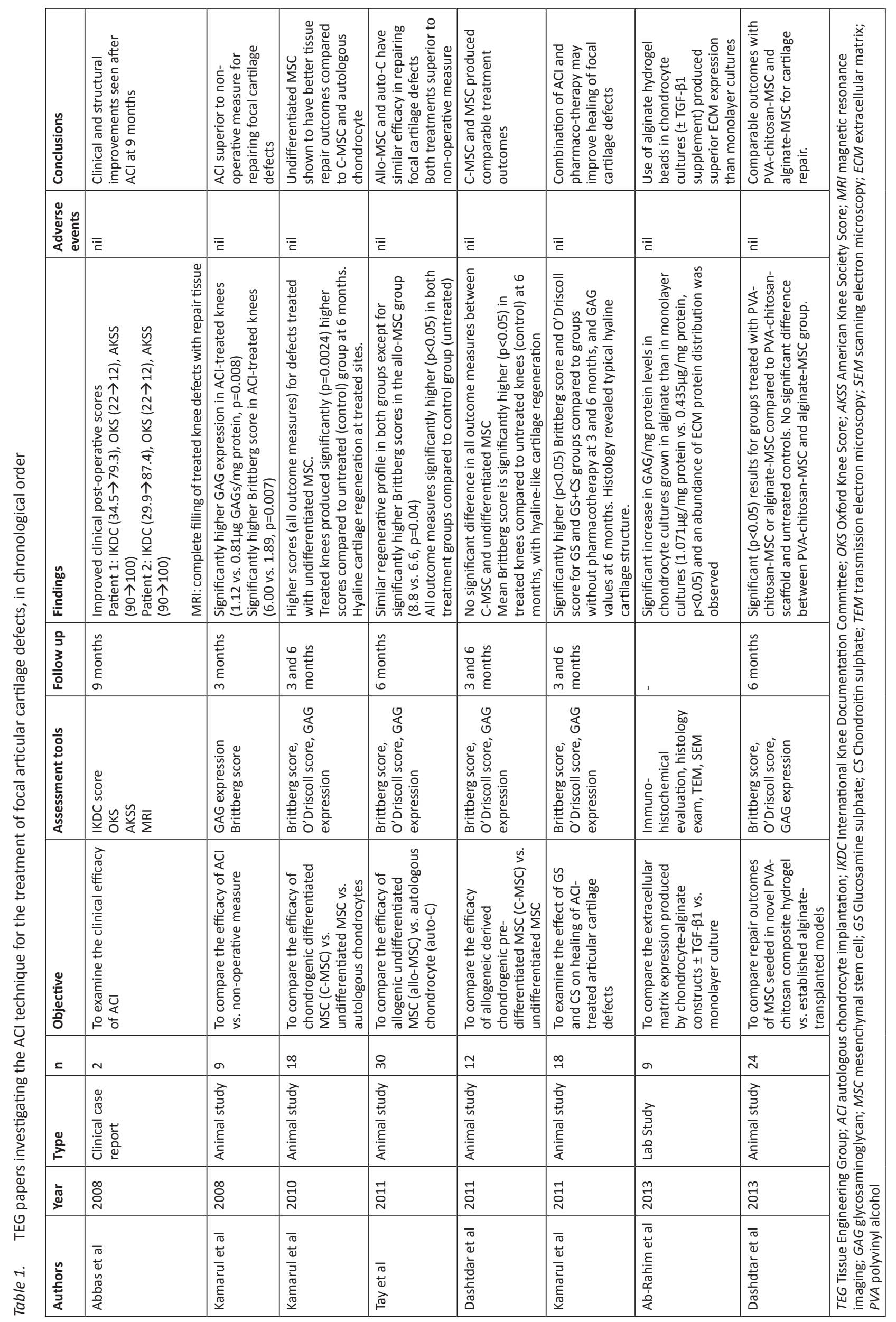


other cell types despite being removed from their original environment (68-69). MSC can be isolated from various tissues, but bone marrow-derived MSC have been found to have better chondrogenic differentiation compared with other sources and are easily attainable (70-71).

To determine the cell source with the highest chondrogenic potential, we conducted a study to compare the treatment outcomes of alginate-embedded allogenic undifferentiated MSC against autologous chondrocytes in the repair of focal articular cartilage defects in 30 rabbit models (72). We found that, apart from significantly $(p=0.04)$ higher Brittberg scores in the allogenic MSC treatment group, both treatments showed similar cartilage regenerative profiles (Table 1).

Similar to the findings of our study, many authors have reported that autologous chondrocytes and MSC produce comparable repair outcomes $(29,73-74)$. Hui et al (73) from NUS compared the efficacy of chondrocytes, MSC, periosteal grafts and mosaicplasty for treating osteochondritis dissecans in rabbits, and reported that cultured chondrocytes and MSC had comparable enhancing effects on the repair of chondral defects, whereas mosaicplasty did well initially and periosteal grafts did less favourably. Yan et al (74) from Peking University evaluated the repaired tissue formed in 36 full-thickness rabbit cartilage defects implanted with chondrocytes, MSC, fibroblasts and human umbilical cord blood stem cells (hUSC-SC), and reported hyaline-like cartilage repair and significantly higher histologic scores in groups treated with chondrocytes and MSC compared with groups treated with fibroblasts and hUSC-SC. Similarly, Nejadnik et al compared the clinical outcomes of 72 patients treated with conventional $\mathrm{ACl}$ with patients treated with autologous MSC and found no discernable differences between the $\mathrm{MSC}$ and $\mathrm{ACl}$ group in terms of clinical outcomes (75).

Another issue to consider with regards to the choice of transplanted cells is the suggestion that lineage committed cells have superior chondrogenic expression markers compared with undifferentiated MSC (76-77). As in-vivo assessments of chondrogenic pre-differentiated MSC to repair cartilage defects had not yet been initiated, we decided to perform a preliminary study in which full-thickness focal cartilage defects were created in 18 rabbit models and treated with either chondrogenic differentiated MSC (CMSC), autologous chondrocytes or undifferentiated MSC (78). Quantification analyses demonstrated higher scores in terms of mean Brittberg score, GAG quantification and histological score for defects treated with undifferentiated MSC compared with ones treated with CMSC and autologous chondrocytes, although these findings were not significant (Table 1). On the other hand, in a subsequent study comparing cartilage repair potential between allogenic-derived CMSC and undifferentiated MSC for full-thickness cartilage defects of 12 rabbits, we observed no significant differences between the Brittberg, O'Driscoll scores, GAG and total protein content when comparing defect sites treated with MSC and CMSC (79) (Table 1). These findings suggest that transplantation of MSC for the repair of articular cartilage defects produces a comparable repair to autologous chondrocytes, irrespective of their state of differentiation. This may have clinical implications forthe wider use of undifferentiated MSC in cell-based therapy, as this option is associated with more simplified and economical laboratory processing. However, as there are no available papers at present with which to compare our findings, these observations are preliminary.

\section{The role of cell carriers and scaffolds}

First-generation (conventional) ACl utilising periosteal grafts, as developed by Peterson et al, was observed to produce good repair outcomes, but this was complicated by periosteal hypertrophy, local morbidity for periosteal harvest and graft failures $(63,64,80,81)$. Second-generation $\mathrm{ACl}$ explored the use of collagen membranes as a replacement for periosteal grafts, and was found to eliminate the drawbacks associated with the use of periosteal flaps with no statistical reduction in clinical outcomes $(61,82)$. However, both first- and second-generation $\mathrm{ACl}$ techniques have been reported to be limited by the risk of cell leakage with inadequate sealing (83) and dedifferentiation of cellular phenotypes cultured in a monolayer culture (65-67).

Recent advances in tissue engineering have led to the development of third-generation $\mathrm{ACl}$, which relies upon utilising scaffolds and cell carriers to mimic a matrix and provide the necessary information or signaling for cell attachment, proliferation and differentiation (84-85). Chondrocytes are embedded into three-dimensional (3D) constructed scaffolds for cell growth, resulting in an 'all-inone' graft that does not need a periosteal cover or fixing stitches and can be trimmed to exactly fit the cartilage defect, effectively avoiding spillover or asymmetric distribution of chondrocytes following implantation. Additionally, it has been suggested that the use of certain scaffolds in chondrocytic cultures can eliminate the phenotypic drift associated with monolayer culture $(65,86)$. This is of particular importance considering that an alteration in the ability of chondrocytes to maintain extracellular matrix expression (ECM) may ultimately lead to inferior repair outcomes in patients.

We decided to study the use of alginate, one of the most studied and applied polymers in the tissue engineering and drug delivery field (85) which is known to improve chondrocyte differentiation in cultures (87-90). To this end, our centre conducted a controlled laboratory experiment where chondrocytes were isolated from rabbit knee articular cartilage and expanded in vitro using a monolayer culture system or alginate chondrocyte construct suspension (91) (Table 1). Results demonstrated a significant increase $(p<0.05)$ in $G A G / m g$ protein levels in chondrocyte cultures grown in alginate construct compared with monolayer cultures. In addition, an abundance of ECM protein distribution surrounding the chondrocytes cultured in alginate hydrogel was observed. 
To support our findings, many other authors have reported encouraging alginate outcomes in in vitro and in vivo studies and concur that cultures of chondrocytes in alginate beads enable chondrocytes to maintain their spherical shape and typical chondrotypic appearance (8788), resulting in significantly raised cartilage formation and particularly increased expression of type II collagen (89-90). Correspondingly, the application of alginate in $\mathrm{ACl}$-treated patients has produced significant clinical improvements at two years, with predominantly hyalinelike repair tissue observed in the majority of patients (92). Other matrix and scaffold materials such as collagen (84, 93-95), hyaluronic acid (96-98), agarose (99), fibrin (100) and polyhydroxyacids (101) have shown equally favourable clinical results in cartilage regeneration. Four comparative studies comparing the use of periosteal- $\mathrm{ACl}$ with collagen (102-103), hyaluronic acid (104) and polyhydroxyacids (105) produced comparable short-term clinical results, suggesting that at present there is no obvious ranking among the currently available scaffolds for clinical use.

In recent years, hybrid scaffolds that combine synthetic and natural polymer have recently been developed in an effort to further enhance the clinical outcome of $\mathrm{ACl}$ led cartilage repair. Naturally derived materials such as alginate often have desirable biological properties but limited mechanical strength or fat degradation profiles (for eventual integration into surrounding tissue). In contrast, synthetic polymers provide an appropriate 3D environment and have the desired mechanical strength but lack the bioactive properties of natural scaffolds. Composite hydrogels are thought to be able to retain the desirable characteristics of both materials, and have been observed to produce encouraging results in in vitro and in vivo experiments (106-109).

Poly-vinyl alcohol (PVA)-chitosan application has been previously described for wound healing $(108,109)$ but its role as a scaffold for MSC in cartilage tissue engineering has not been demonstrated. Our group investigated the efficacy of a novel PVA-chitosan composite hydrogel compared with previously established alginate-transplanted models (107). In this study, a medial femoral condyle defect was created in both knees of 24 rabbit models and transplanted, after three weeks, with PVA-chitosan-MSC, PVA-chitosan scaffold alone, alginate-MSC or alginate alone. We observed that the morphological and histological analysis showed significantly better $(p<0.05)$ tissue repair when treated with PVA-chitosan-MSC or alginate MSC compared to the scaffold alone and the untreated control (Table 1). No significant difference was observed between the PVA-chitosan-MSC and alginate-MSC groups. These findings suggest that the use of scaffolds and cell carriers (e.g. alginate, PVAchitosan) in the $\mathrm{ACl}$ technique may provide more favourable $\mathrm{ECM}$ expression compared to conventional $\mathrm{ACl}$ utilising monolayer cultures, by maintaining cell morphology within a conductive culture environment.

Although the induction of scaffolds and cell carriers into the $\mathrm{ACl}$ technique has been reported by many authors to be favourable, evidence suggests that while third- generation $\mathrm{ACl}$, utilising scaffolds and cell carriers, seems to promote chondrocyte differentiation and formation of cartilage matrix, it has not resulted in superior clinical results when compared with conventional $\mathrm{ACl}$. The five comparative controlled clinical trials available at present demonstrated similar results when comparing second- and third-generation $\mathrm{ACl}$ against first-generation $\mathrm{ACl}(82,102$ 105). However, the authors did note that the use of scaffolds reduced the incidence of periosteal hypertrophy $(82,102)$.

\section{The role of local and systemic pharmacological agents}

Another approach in augmenting tissue differentiation and cell activity in cartilage tissues is via the introduction of biochemical modulators. Glucosamine sulphate (GS) and chondroitin sulphate (CS) are the two most frequently prescribed nutritional supplements for the treatment of osteoarthritis (110), and have been shown to have substantial clinical efficacy in several osteoarthritis studies (111-114). In vitro, GS and CS have been reported to stimulate the synthesis of proteoglycans by cultivated human chondrocytes (115-118). Although investigated extensively in osteoarthritis, the use of these pharmacological agents for the repair of focal chondral lesions has not been explored.

To elicit the role of GS and CS in enhancing ACl-led focal cartilage repair, our centre conducted a preliminary laboratory experiment to establish the effects of oral administration of GS and CS on the healing rate of $\mathrm{ACl}$-repaired chondral lesions in 18 rabbits (119). We observed significantly higher $(p<0.05)$ Brittberg scores and modified O'Driscoll scores in groups treated with a combination of $\mathrm{ACl}$ and pharmacotherapy (Group $\mathrm{ACl}+\mathrm{GS}$ and Group $\mathrm{ACl}+\mathrm{GS}+\mathrm{CS}$ ) compared with the $\mathrm{ACl}$ without pharmacotherapy group at three months, and significantly higher $(p<0.05)$ GAG content at six months (Table 1). Based on the results of our study and those reported by others $(120,121)$, it is suggested that there may be a functional role for GS and CS in augmenting the restoration of $\mathrm{ACl}$-repaired chondral lesions. However, as there are no available papers at present with which to compare our findings, these observations are preliminary.

\section{Conclusion}

Earlier systematic reviews examining the evidence for conventional $\mathrm{ACl}$ by other authors concluded that there was insufficient evidence in the existing literature to determine whether or not conventional $\mathrm{ACl}$ was superior in the treatment of focal articular cartilage defects (4349). However, the $\mathrm{ACl}$ technique has evolved considerably over the past few years. Not only have biomaterials been introduced into the field, MSC has emerged as a promising potential alternative cell source to autologous chondrocytes. Our six years of experience in cell-based therapy, which consists of one clinical study, six animal 
studies and one laboratory study, suggests that the $\mathrm{ACl}$ technique is a feasible technique for the treatment of focal articular cartilage defects. Our study has shown that the ECM expression produced by a chondro-conductive scaffold construct (e.g. chondrocyte-alginate construct) is superior to the ECM expression produced by chondrocytes grown in monolayer cultures. Moreover, by utilising a 3D chondro-conductive scaffold, the issues of periosteal hypertrophy, cell leakage and dedifferentation of cellular phenotypes cultured in a monolayer culture (63-67, 80$81,83)$ associated with conventional $\mathrm{ACl}$ can be avoided. Our study has also demonstrated that autologous chondrocytes and MSC have comparable regenerative profiles, irrespective of the state of MSC differentiation. Owing to the ease of harvesting and their multi-potential ability, MSC represent a feasible alternative cell source that can be exploited in repairing articular cartilage defects. Finally, our study has also preliminarily shown the potential of oral pharmacotherapy (GS and CS) in enhancing the healing of $\mathrm{ACl}$-led repair of focal cartilage defects. No adverse reactions were observed in any of our clinical and animal studies. On the whole, these findings collectively suggest that the $\mathrm{ACl}$ technique incorporating 1) autologous chondrocytes or MSC; 2 ) chondro-conductive scaffolds and cell carriers; and 3) oral pharmacotherapy, is a safe and efficient therapeutic option for the treatment of articular cartilage defects of the knee. We are excited to be embarking, in the near future, on research into further methods of refining the $\mathrm{ACl}$ technique, including mechanotransduction and gene manipulation. Based on our six years' experience in cell-based therapy, we are optimistic that we will be able to achieve an effective and reproducible solution to the repair of the notoriously difficult to treat chondral lesions.

\section{Acknowledgement}

The authors are grateful to HIR-MOHE research grant initiative, University of Malaya (UM.C/625/1/HIR/MOHE/ $\mathrm{CHAN} / 03$ ) for bearing the administrative costs.

\section{References}

1. Wluka AE, Ding C, Jones $G$, et al. The clinical correlates of articular cartilage defects in symptomatic knee osteoarthritis: a prospective study. Rheumatology (Oxford) 2005; 44:1311-16.

2. Ding C, Garnero P, Cicuttini F, et al. Knee cartilage defects: association with early radiographic osteoarthritis, decreased cartilage volume, increased joint surface area and type II collagen breakdown. Osteoarthr Cartilage. 2005; 13(3):198-205.

3. Veerapen K, Wigley RD, Valkenburg H. Musculoskeletal pain in Malaysia: a COPCORD study. J Rheumatol. 2007; 34(1):207-13.

4. Li YP, Wei XC, Zhou JM, et al. The age-related changes in cartilage and osteoarthritis. Biomed Res Int 2013; 2013:916530.
5. Hui JHP, Ouyang HW, Hutmacher DW, et al. Mesenchymal stem cells in musculoskeletal tissue engineering: a review of recent advances in National University of Singapore. Ann Acad Med Singapore 2005; 34:206-212.

6. Bert JM, Maschka K. The arthroscopic treatment of unicompartmental gonarthrosis: a five-year followup study of abrasion arthroplasty plus arthroscopic debridement and arthroscopic debridement alone. Arthroscopy. 1989; 5(1):25-32.

7. Baumgartner MR, Cannon WD, Vittori JM, et al. Arthroscopic debridement of the arthritic knee. Clin Orthop Relat Res 1990; 253:197-202.

8. Timoney JM, Kneisl JS, Barrack RL, et al. Arthroscopy in the osteoarthritic knee. Long-term follow-up. Orthop Rev. 1990; 19(4):371-73, 376-9.

9. Jackson RW, Dieterichs C. The results of arthroscopic lavage and debridement of osteoarthritic knees based on the severity of degeneration: a 4- to 6-year symptomatic follow-up. Arthroscopy. 2003; 19(1):13-20.

10. Minas T, Nehrer S. Current concepts in the treatment of articular cartilage defects. Orthopedics. 1997; 20(6):525-38.

11. Gilbert JE. Current treatment options for restoration of articular cartilage. Am J Knee Surg. 1998; 11(1):426.

12. Azer NM, Winalski CS, Minas T. MR imaging for surgical planning and postoperative assessment in early osteoarthritis. Radiol Clin North Am. 2004; 42(1):43-60.

13. Steadman JR, Briggs KK, Rodrigo JJ, et al. Outcomes of microfracture for traumatic chondral defects of the knee: Average 11-year follow up. Arthroscopy. 2003; 19(5):477-84.

14. Mithoefer K, Williams RJ $3^{\text {rd }}$, Warren RF, et al. The microfracture technique for the treatment of articular cartilage lesions in the knee. A prospective cohort study. J Bone Joint Surg Am. 2005; 87(9):191120.

15. Johnson LL. Arthroscopic abrasion arthroplasty: a review. Clin Orthop Relat Res. 2001; (391 Suppl):S306-17.

16. Steinwachs MR, Guggi T, Kreuz PC. Marrow stimulation techniques. Injury. 2008; 39 (Suppl 1):S26-31.

17. Redman SN, Oldfield SF, Archer CW. Current strategies for articular cartilage repair. Eur Cell Mater. 2005; 9(23-32):23-32.

18. Kreuz PC, Steinwachs MR, Erggelet C, et al. Results after microfracture of full-thickness chondral defects in different compartments in the knee. Osteoarthr Cartilage. 2006; 14(11): 1119-25.

19. Homminga GN, Bulstra SK, Bouwmeester PSM, et al. Perichondral grafting for cartilage lesions of the knee. J Bone Joint Surg Br. 1990; 72(6):1003-7.

20. Bouwmeester SJM, Beckers JMH, Kuijer R, et al. Long-term results of rib perichondrial grafts for repair of cartilage defects in the human knee. Int Orthop. 1997; 21(5):313-17. 
21. Convery FR, Meyers MH, Akeson WH. Fresh osteochondral allografting of the femoral condyle. Clin Orthop Relat Res. 1991; (273):139-45.

22. Garrett JC. Fresh osteochondral allografts for treatment of articular defects in osteochondritis dissecans of the lateral femoral condyle in adults. Clin Orthop Relat Res 1994; 303:33-7.

23. Hangody L, Kish G, Karpati Z. Mosaicplasty for the treatment of articular cartilage defects: application in clinical practice. Orthopedics. 1998; 21(7):751-56.

24. Hangody L, Fules P. Autologous osteochondral mosaicplasty for the treatment of full-thickness defects of weight-bearing joints: ten years of experimental and clinical experience. J Bone Joint Surg Am 2003; 85-A Suppl 2:25-32.

25. Jakob RP, Franz T Gautier E, et al. Autologous osteochondral grafting in the knee: Indication, results and reflections. Clin Orthop Relat Res. 2002; 401:170-84.

26. Ueblacker $P$, Burkart $A$, Imhoff $A B$. Retrograde cartilage transplantation on the proximal and distal tibia. Arthroscopy. 2004; 20(1):73-8.

27. Bhosale AM, Richardson JB. Articular cartilage: structure, injuries and review of management. $\mathrm{Br}$ Med Bull 2008; 87:77-95.

28. Peterson L, Menche D, Grande D et al. Chondrocyte transplantation: an experimental model in the rabbit. Trans Orthop Res Soc 1984; 9:218.

29. Wakitani S, Goto T, Pineda SJ, et al. Mesenchymal cell-based repair of large, full-thickness defects of articular cartilage. J Bone Joint Surg Am. 1994; 76(4):579-92.

30. Minguell JJ, Erices A, Conget P. Mesenchymal stem cells. Exp Biol Med. 2001; 226(6):507-20.

31. Caplan Al. Mesenchymal stem cells. J Orthop Res. 1991; 9(5):641-50.

32. Naveen S, Robson N, Kamarul T. Comparative analysis of autologous chondrocyte implantation and other treatment modalities: a systematic review. Eur J Orthop Surg Traumatol. 2012; 22(2):89-96.

33. Visna P, Pasa L, Hart R, et al. [Treatment of deep chondral defects of the knee using autologous chondrocytes cultured on a support--results after one year]. Acta Chir Orthop Traumatol Cech 2003; 70:356-362.

34. Kon E, Gobbi A, Filardo G, et al. Arthroscopic secondgeneration autologous chondrocyte implantation compared with microfracture for chondral lesions of the knee: prospective nonrandomized study at 5 years. Am J Sports Med 2009; 37:33-41.

35. Saris DB, Vanlauwe J, Victor J, et al. Treatment of symptomatic cartilage defects of the knee: characterized chondrocyte implantation results in better clinical outcome at 36 months in a randomized trial compared to microfracture. Am J Sports Med 2009 37:10S-19S.

36. Basad E, Ishaque B, Bachmann G, et al. Matrix-induced autologous implantation versus microfracture in the treatment of cartilage defects of the knee: a 2-year randomised study. Knee Surg Sports Traumatol Arthrosc 2010; 18:519-527.

37. Crawford DC, DeBerardino TM, Williams RJ $3^{\text {rd }}$. NeoCart, an autologous cartilage tissue implant, compared with microfracture for treatment of distal femoral cartilage lesions: an FDA phase-II prospective, randomized clinical trial after two years. J Bone Joint Surg Am 2012 94:979-989.

38. Bentley G, Biant LC, Vijayan S, et al. Minimum tenyear results of a prospective randomised study of autologous chondrocyte implantation versus mosaicplasty for symptomatic articular cartilage lesions of the knee. J Bone Joint Surg Br 2012; 94:504-509.

39. Knutsen G, Drogset JO, Engebretsen L, et al. A randomized trial comparing autologous chondrocyte implantation with microfracture. Finding at five years. J Bone Joint Surg Am 2007; 89:2105-2112.

40. Dozin B, Malpeli M, Cancedda R, et al. Comparative evaluation of autologous chondrocyte implantation and mosaicplasty: a multicentered randomized clinical trial. Clin J Sport Med 2005; 15:220-226.

41. Lim HC, Bae JH, Song SH, et al. Current treatments of isolated articular cartilage lesions of the knee achieve similar outcomes. Clin Orthop Relat Res 2012; 470:2261-2267.

42. Horas U, Pelinkovic D, Herr G, et al. Autologous chondrocyte implantation and osteochondral cylinder transplantation in cartilage repair of the knee joint. A prospective, comparative trial. J Bone Joint Surg Am 2003; 85-A:185-192.

43. Wasiak J, Clar C, Villanueva E. Autologous cartilage implantation for full thickness articular cartilage defects of the knee. Cochrane Database Syst Rev 2006 19:CD003323.

44. Magnussen RA, Dunn WR, Carey JL, et al. Treatment of focal articular cartilage defects in the knee: a systematic review. Clinical Orthop Relat Res 2008; 466:952-962.

45. Bekkers JE, Inklaar M, Saris DB. Treatment selection in articular cartilage lesions of the knee: a systematic review. Am J Sports Med 2009; 37:148S-155S.

46. Vavken P, Samartzis D. Effectiveness of autologous chondrocyte implantation in cartilage repair of the knee: a systematic review of controlled trials. Osteoarthr Cartilage 2010; 18:857-863.

47. Harris JD, Siston RA, Pan X, et al. Autologous chondrocyte implantation: a systematic review. J Bone Joint Surg Am 2010; 92:2220-2233.

48. Vasiliadis HS, Wasiak J, Salanti G. Autologous chondrocyte implantation for the treatment of cartilage lesions of the knee: a systematic review of randomized studies. Knee Surg Sports Traumatol Arthrosc 2010; 18:1645-1655.

49. Benthien JP, Schwaninger M, Behrens P. We do not have evidence based methods for the treatment of cartilage defects in the knee. Knee Surg Sports Traumatol Arthrosc 2011; 19:543-552.

50. Abbas AA, Mohamad JA, Lydia AL. Early experience in autologous chondrocyte transplantation: a report 
of 2 cases. J Asean Orthopaedic Association. 2008; 19(1):13-21.

51. Sasisekharan R, Raman R, Prabhakar V. Glycomics approach to structure-function relationships of glycosaminoglycans. Annu Rev Biomed Eng 2006; 8:181-231.

52. Smith GD, Taylor J, Almqvist KF, et al. Arthroscopic assessment of cartilage repair: a validation study of 2 scoring systems. Arthroscopy. 2005; 21(12):1462-67.

53. Rutgers $M$, van Pelt MJ, Dhert WJ, et al. Evaluation of histological scoring systems for tissue-engineered, repaired and osteoarthritic cartilage. Osteoarthr Cartilage. 2010; 18(1): 12-23.

54. Kamarul T, Selvaratnam L, Masjuddin T, et al. Autologous chondrocyte transplantation in the repair of full-thickness focal cartilage damage in rabbits. $J$ Orthop Surg. 2008; 16(2):84-7.

55. Grande DA, Pitman MI, Peterson L, et al. The repair of experimentally produced defects in rabbit articular cartilage by autologous chondrocyte transplantation. J Orthop Res. 1989; 7(2):208-18.

56. Brittberg $M$, Nilsson A, Lindahl A, et al. Rabbit articular cartilage defects treated with autologous cultured chondrocytes. Clin Orthop Relat Res. 1996; (326):270-83.

57. Brittberg M, Lindahl A, Nilsson A, et al. Treatment of deep cartilage defects in the knee with autologous chondrocyte transplantation. N Engl J Med. 1994; 331(14):889-95.

58. Richardson JB, Caterson B, Evans EH, et al. Repair of human articular cartilage after implantation of autologous chondrocytes. J Bone Joint Surg Br. 1999; 81(6):1064-8.

59. Minas T. Autologous chondrocyte implantation for focal chondral defects of the knee. Clin Orthop Rel Res. 2001; (Suppl 391):S349-S361.

60. Peterson L, Brittberg M, Kiviranta I, et al. Autologous chondrocyte transplantation: Biomechanics and longterm durability. Am J Sports Med. 2002; 30(1):2-12.

61. Steinwachs M, Kreuz PC. Autologous chondrocyte implantation in chondral defects of the knee with a type I/III collagen membrane: a prospective study with a 3-year follow-up. Arthroscopy. 2007; 23(4):381-7.

62. Peterson L, Minas T, Brittberg $M$ et al. Two- to 9-year outcome after autologous chondrocyte transplantation of the knee. Clin Orthop. 2000; (374):212-34.

63. Kreuz PC, Steinwachs M, Erggelet C et al. Classification of graft hypertrophy after autologous chondrocyte implantation of full-thickness chondral defects in the knee. Osteoarthr Cartilage. 2007; 15(12):1339-47.

64. Niemeyer P, Pestka JM, Kruez PC et al. Characteristic complications after autologous chondrocyte implantation for cartilage defects of the knee joint. Am J Sports Med. 2008; 36(11):2091-99.

65. Benya PD, Shaffer JD. Dedifferentiated chondrocytes reexpress the differentiated collagen phenotype when cultured in agarose gels. Cell. 1982; 30(1):215-24.
66. Shakibaei M, Schroter-Kermani C, Merker HJ. Matrix changes during long-tern cultivation of cartilage (organoid or high-density cultures). Histol Histopathol. 1993; 8(3):463-70.

67. Lin Z, Fitzgerald JB, Xu J et al. Gene expression profiles of human chondrocytes during passaged monolayer cultivation. J Orthop Res. 2008; 26(9):1230-7.

68. Pittenger MF, Mackay AM, Beck SC. Multilineage potential of adult human mesenchymal stem cells. Science. 1999; 284(5411):143-7.

69. Ohgushi H, Caplan Al. Stem cell technology and bioceramics: from cell to gene engineering. J Biomed Mater Res. 1999; 48(6):913-27.

70. Wakitani S, Imoto K, Yamamoto T, et al. Human autologous culture expanded bone marrow mesenchymal cell transplant for repair of cartilage defects in osteoarthritic knees. Osteoarthr Cartilage. 2002; 10(3):199-206.

71. Bernardo ME, Zaffaroni N, Novara F, et al. Human bone marrow derived mesenchymal stem cells do not undergo transformation after long-term in vitro culture and do not exhibit telomere maintenance mechanisms. Cancer Res. 2007; 67(19):9142-9.

72. Tay LX, Ahmad RE, Dashtar $\mathrm{H}$, et al. Treatment outcomes of alginate-embedded allogenic mesenchymal stem cells versus autologous chondrocytes for the repair of focal articular cartilage defects in a rabbit model. Am J Sports Med. 2012; 40(1):83-90.

73. Hui JH, Chen F, Thambyah A, et al. Treatment of chondral lesions in advanced osteochondritis dissecans: a comparative study of the efficacy of chondrocytes, mesenchymal stem cells, periosteal graft, and mosaicplasty (osteochondral autograft) in animal models. J Pediatr Orthop. 2004; 24(4):427-433.

74. Yan H, Yu C. Repair of full-thickness cartilage defects with cells of different origin in a rabbit model. Arthroscopy. 2007; 23(2):178-187.

75. Nejadnik H, Hui JH, Choong EPF, et al. Autologous bone marrow-derived mesenchymal stem cells versus autologous chondrocyte implantation: An observational cohort study. Am J Sports Med. 2010; 38(6):1110-6.

76. McBride Sh, Knothe Tate ML. Modulation of stem cell shape and fate $A$ : the role of density and seeding protocol on nucleus shape and gene expression. Tissue Eng Part A. 2008; 14(9):1561-72.

77. Ullah $M$, Eucker J, Sittinger $M$ et al. Mesenchymal stem cells and their chondrogenic differentiated and dedifferentiate progeny express chemokine receptor CCR9 and chemotactically migrate toward CCL25 or serum. Stem Cell Res Ther. 2013; 4(4):99.

78. Kamarul T, Tay T, Dashtar $\mathrm{H}$ et al. The use of chondrogenic differentiated mesenchymal stem cells in treating focal cartilage damage: preliminary study in animal model. Eur Cell Mater. 2010; 20(Suppl 2):S45.

79. Dashtdar H, Rothan HA, Tay $\mathrm{T}$, et al. A preliminary study comparing the use of allogenic chondrogenic predifferentiated and undifferentiated mesenchymal 
stem cells for the repair of full thickness articular cartilage defects in rabbits. J Orthop Res. 2011; 29(9):1336-42.

80. Minas T, Chiu R. Autologous chondrocyte implantation. Am J Knee Surg. 2000; 13(1):41-50.

81. Harris JD, Siston RA, Brophy RH, et al. Failures, reoperations, and complications after autologous chondrocyte implantation - a systematic review. Osteoarthr Cartilage. 2011; 19(7):779-91.

82. Gooding CR, Bartlett W, Bentley G, et al. A prospective, randomized study comparing two techniques of autologous chondrocyte implantation for osteochondral defects in the knee: periosteum covered versus type I/II collagen covered. Knee. 2006; 13(3):203-10.

83. Sohn DH, Lottman LM, Lum LY et al. Effect of gravity on localization of chondrocytes implanted in cartilage defects. Clin Orthop Relat Res. 2002; (394):254-62.

84. Cherubino P, Grassi FA, Bulgheroni P, et al. Autologous chondrocyte implantation using a bilayer collagen membrane: A preliminary report. J Orthop Surg. 2003: 11(1):10-15.

85. Malafaya PB, Silva GA, Reis RL. Natural-origin polymers as carriers and scaffolds for biomolecules and cell delivery in tissue engineering applications. Adv Drug Deliv Rev. 2007; 59(4-5):207-33.

86. Bonaventure J, Kadhom N, Cohen-Solal L, et al. Reexpression of cartilage-specific genes by dedifferentiated human articular chondrocytes cultured in alginate beads. Exp Cell Res. 1994; 212(1):97-104.

87. Hauselmann HJ, Fernandes RJ, Mok SS et al. Phenotypic stability of bovine articular chondrocytes after long-term culture in alginate beads. J Cell Sci. 1994; 107(1):17-27.

88. Lin YJ, Yen CN, Hu YC et al. Chondrocytes culture in three-dimensional porous alginate scaffolds enhanced cell proliferation, matrix synthesis and gene expression. J Biomed Mater Res A. 2009; 88(1):23-33.

89. Diduch DR, Jordan LC, Mierisch CM, et al. Marrow stromal cells embedded in alginate for repair of osteochondral defects. Arthroscopy. 2000; 16(6):571-7.

90. Marijnissen WJ, van Osch GJ, Aigner J, et al. Alginate as a chondrocyte-delivery substance in combination with a non-woven scaffold for cartilage tissue engineering. Biomaterials. 2002; 23(6):1511-7.

91. Abd-Rahim S, Selvaratnam L, Raghavendran HR et al. Chondrocyte-alginate constructs with or without TGF- $\beta 1$ produces superior extracellular matrix expression than monolayer cultures. Mol Cell Biochem. 2013; 376(1-2):11-20.

92. Selmi TAS, Verdonk $P$, Chambat $P$ et al. Autologous chondrocyte implantation in a novel alginate-agarose hydrogel: outcome at two years. J Bone J Surg Br. 2008; 90(5):597-604.

93. Behrens P, Bitter T, Kurz B et al. Matrix-assisted autologous chondrocyte transplantation/ implantation (MACT/MACl) - 5 years follow-up. Knee 2006; 194-202.

94. Trattnig S, Ba-Ssalamah A, Pinker $\mathrm{K}$ et al. Matrixbased autologous chondrocyte implantation for cartilage repair: noninvasive monitoring by highresolution magnetic resonance imaging. Magn Reson Imaging. 2005; 23(7):779-87.

95. Marlovits S, Aldrian S, Wondrasch B et al. Clinical and radiological outcomes 5 years after matrix-induced autologous chondrocyte implantation in patients with symptomatic, traumatic chondral defects. Am J Sports Med. 2012; 40(10):2273-80.

96. Pavesio A, Abatangelo G, Borrione A et al. Hyaluronanbased scaffolds (Hyalograft $\mathrm{C}$ ) in the treatment of knee cartilage defects: preliminary clinical findings. Novartis Found Symp 2003; 249:203-17.

97. Marcacci M, Berruto M, Brocchetta D et al. Articular cartilage engineering with Hyalograft C: 3-year clinical results. Clin Orthop Relat Res 2005; 435:96105.

98. Nehrer S, Domayer S, Dorotka R et al. Three-year clinical outcome after chondrocyte transplantation using a hyaluronan matrix for cartilage repair; Eur J Radiol. 2006; 57(1):3-8.

99. Buschmann MD, Yehezkiel AG, Grodzinsky AJ et al. Chondrocytes in agarose culture synthesize a mechanically functional extracellular matrix. J Orthop Res. 1992; 10(6):745-58.

100. Visna P, Pasa L, Hart R et al. Treatment of deep chondral defects of the knee using autologous chondrocytes cultured on a support - results after one year. Acta Chir Orthop Traumatol Cech. 2003; 70(6):356-62.

101. Ossendorf C, Kaps C, Kreutz PC et al. Treatment of posttraumatic and focal osteoarthritic cartilage defects of the knee with autologous polymer-based three-dimensional chondrocyte grafts: 2-year clinical results. Arthritis Res Ther. 2007; 9(2):R41.

102. Bartlett W, Skinner JA, Gooding CR et al. Autologous chondrocyte implantation versus matrix-induced autologous chondrocyte implantation for osteochondral defects of the knee: a prospective, randomised study. J Bone J Surg Br. 2005; 87(5):640-5.

103. Zeifang F, Oberle D, Nierhoff C, Richter W, Moradi $B$, Schmitt H. Autologous chondrocyte implantation using the original periosteum-cover technique versus matrix-associated autologous chondrocyte implantation: a randomized clinical trial. Am J Sports Med. 2010; 38(5):924-933.

104. Mandrefini M, Zerbinati F, Gildone A et al. Autologous chondrocyte implantation: a comparison between an open periosteal-covered and an arthroscopic matrix-guided technique. Acta Orthop Belg. 2007; 73(2):207-18.

105. Erggelet C, Kreutz PC, Mrosek EH et al. Autologous chondrocyte implantation versus $\mathrm{ACl}$ using 3D-bioresorbable graft for the treatment of large full-thickness cartilage lesions of the knee. Arch Orthop Trauma Surg. 2010; 130(8):957-64. 
106. Kundu J, Shim JH, Jang J et al. An additive manufacturing-based PCL-alginate-chondrocyte bioprinted scaffold for cartilage tissue engineering. J Tissue Eng Regen Med 2013; [Epub ahead of print]

107. Dashtdar H, Murali MR, Abbas AA et al. PVAchitosan composite hydrogel versus alginate beads as a potential mesenchymal stem cell carrier for the treatment of focal cartilage defects. Knee Surg Sports Traumatol Arthrosc 2013; [Epub ahead of print]

108. Nacer KA, Mahlous M, Tahtat D et al. Evaluation of healing activity of PVA/chitosan hydrogels on deep second degree burn: pharmacological and toxicological tests. Burns. 2013; 39(1):98-104.

109. Sung JH, Hwang MR, Kim JO et al. Gel characterization and in vivo evaluation of minocycline-loaded wound dressing with enhanced wound healing using polyvinyl alcohol and chitosan. Int J Pharm. 2010; 392(1-2):232-40.

110. McAlindon TE, LaValley MP, Gulin JP, et al. Glucosamine and chondroitin for treatment of osteoarthritis: a systematic quality assessment and meta-analysis. JAMA. 2000; 283(11):1469-75.

111. Noack W, Fischer M, Forster KK, et al. Glucosamine sulfate in osteoarthritis of the knee. Osteoarthr Cartilage. 1994; 2(1):51-9.

112. Reginster JY, Deroisy R, Rovati LC, et al. Long-term effects of glucosamine sulphate on osteoarthritis progression: a randomized, placebo-controlled clinical trial. Lancet. 2001; 357(9252):251-6.

113. Richy F, Bruyere O, Ethgen $O$, et al. Structural and symptomatic efficacy of glucosamine and chondroitin in knee osteoarthritis: A comprehensive metaanalysis. Arch Intern Med. 2003; 163(13):1514-22.

114. Sawitzke AD, Shi H, Finco MF, et al. The effect of glucosamine and/ or chondroitin sulphate on progression of knee osteoarthritis: a GAIT report. Arthritis Rheum. 2008; 58(10):3183-91.

115. Baessleer C, Henrotin Y, Franchimont P. In-vitro evaluation of drugs proposed as chondroprotective agents. Int J Tiss React. 1992; 14(5):231-41.

116. Baessleer C, Rovati L, Franchimont P. Stimulation of proteoglycan production by glucosamine sulfate in chondrocytes isolated from human osteoarthritic articular cartilage in vitro. Osteoarthr Cartilage. 1998; 6(6):427-34.

117. Dodge GR, Jiminez SA. Glucosamine sulfate modulates the levels of aggrecan and matrix metaaloproteinase-3 synthesized by cultured human osteoarthritis articular chondrocytes. Osteoarthr Cartilage. 2003; 11(6):424-32.

118. Varghese $S$, Theprungsirikul $P$, Sahani $S$, et al. Glucosamine modulates chondrocyte proliferation, matrix synthesis, and gene expression. Osteoarthr Cartilage. 2007; 15(1):59-68.

119. Kamarul $\mathrm{T}, \mathrm{Ab}$-Rahim $\mathrm{S}$, Tumin $\mathrm{M}$, et al. A preliminary study of the effects of glucosamine sulphate and chondroitin sulphate on surgically treated and untreated focal cartilage damage. Eur Cell Mater 2011; 21:259-71.

120. Chan PS, Caron JP, Rosa GJ, et al. Glucosamine and chondroitin sulfate regulate gene expression and synthesis of nitric oxide and prostaglandin E (2) in articular cartilage explants. Osteoarthr Cartilage. 2005; 13(5):387-94.

121. Homandberg GA, Guo D, Ray LM et al. Mixtures of glucosamine and chondroitin sulfate reverse fibronectin fragment mediated damage to cartilage more effectively than either agent alone. Osteoarthr Cartilage. 2006; 14(8):793-806. 